\title{
Utilization of Organic and Inorganic Waste Diversification to Improve Families Income in Panggung Jati Taktakan Serang
}

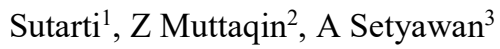 \\ \{1 sutarti86@gmail.com, ${ }^{2}$ d.zaey.vu@gmail.com, ${ }^{3}$ agus.setyawan@hotmail.com\} \\ ${ }^{1}$ Computer System Department, Faculty of Information Technology, Universitas Serang Raya, \\ Serang, Indonesia \\ ${ }^{2,3}$ Information System Department, Faculty of Information Technology, Universitas Serang Raya, \\ Serang, Indonesia
}

\begin{abstract}
Waste was one of the problems faced by the people of Panggung Jati Urban Village. Waste management in Panggung Jati wasn't optimized and even trash was being dumped carelessly. People's yards have not been fully utilized. This community service aims to provide knowledge for the woman of Panggung Jati residents in the utilization of diversified waste both organic and non-organic waste so it can increase family income. In addition, it also motivates the using of yard to plant vegetables. This activity was carried out in the form of seminars and training. Besides that, participants also watched videos of model areas in managing waste and had succeeded in making waste as a source of income. The results obtained from this activity are the people of Panggung Jati know and understand about processing organic and non-organic waste, understanding how to process organic and non-organic waste to be useful item, and more motivated to manage and process household-based waste. In addition, residents had more motivation of farming in the yard. For people who are busy, they can use trash banks as a center for community waste management.
\end{abstract}

Keywords: Diversification, Income, Inorganic, Organic, Utilization, Waste.

\section{Introduction}

Waste is still one of the problems in Indonesia. The national waste issue is quite worrying. Currently, Indonesia is the second highest contributor of plastic waste to the sea. Increased amount of waste will increase the problem as people have poor behaviors regarding waste by littering in roads and rivers and also not using the available trash cans. These behaviors can be observed in anyone regardless of social status, e.g. people still litter in government offices, schools and campuses. This problem grows as the population increases, as more products are consumed and more waste is produced [1]. Increasing amount of waste is also cause by increasing number of culinary businesses which produce waste every day. Waste is also produced by technological development as people are more consumptive and replace old technology with the new one.

Littering happens everywhere although the government plans for Indonesia to be wastefree by 2020 . Being waste-free by 2020 doesn't mean there is no waste at all. It's about 
reducing waste product and processing waste, changing view of waste into economic goods which can be utilize, and reducing the negative effects of waste.

Waste is unwanted remains after the end of a process [2]. Organic waste produces bad smell and has bad impacts on health. Plastic waste is already a national issue related with environmental sustainability because plastic waste is dangerous and difficult to manage [3]. Other inorganic waste will also pollute the environment, threatening life an ecosystem. Actually, if managed well, waste can be an extra source of income.

Panggung Jati Urban Village is located in Taktakan Sub-district, Serang, Banten, with an area of 272.45 Ha. Geographically, it's bordered by Drangong and Lialang in the north, Kuranji and Pancur in the south, Lontar Baru in the east and Kalang Anyar in the west. The population of Panggung Jati is 6.043 spread in some villages, including Umbul Kapuk, Ciolang Jaya, Kalanggaran, West Panggung Jati, Parumasan Baru, East Panggung Jati, Panggung Jati Baru, Kamalaka, Taman Widya Asri, Queen Garden, Pantogan, Pepabri, Bukit Kuranji, Long Jaha and Long Jaha Baru [4].

Waste management in Panggung Jati was done independently in each household. Most people throw away their waste to waste disposal. Some even burn waste in their yards. A small number of people still litter plastic wastes on the roads and yards. However, some people sort their household wastes. They sorted waste and sold it to junkman who goes around the Panggung Jati. Meanwhile, waste which can't be sold (including organic waste) is disposed in temporary waste storage in front of people's houses. The waste is regularly collected by waste collectors and disposed in disposed in final landfill. In landfill, the waste is burnt. People's yards are also not utilized optimally. Some land areas are still empty and filled with grass. A small land on the sides of the roads are also not used well.

Therefore, Community Service Program was performed to:

1. Motivate people to realize Waste-Free Indonesia by 2020.

2. Educate people to use diversification of organic and inorganic wastes.

3. Motivate people to process and manage household waste.

4. Improve the families income by creating things using waste and establishing trash bank.

5. Promoting utilization of yard to plant vegetables and medicinal plants.

The target of the community service was the community of Panggung Jati, by involving village cadres, i.e.: PKK (family welfare development) cadres, Posyandu (Maternal and Child Health Services) cadres, public figures and housewive. The participants of the seminar were expected to be agents of change in their community.

\section{Methods}

Before holding the seminar, the team survey Panggung Jati. Then, interview was conducted with village officials, public figures and housewives. After collecting data, the seminar was planned. The Seminar was held on May 12, 2018 in the hall of Panggung Jati, involving 17 college students of group 29 of KKM (Community Service Program) Universitas Serang Raya as the organizers and two KKM supervisor as instructor. The activity was attended by 27 participants who represented the RT (Neighborhood Association) in Panggung Jati. The activities were: 
a. Field Analysis

The team were surveying the service location, studying literature, having discussion with headman of Panggung Jati and other village officials who were going to help the community service.

b. Program Socialization

Program socialization was performed in Panggung Jati by distributing brochures and information through forum in Panggung Jati.

c. Team Formation

Team formation was performed in the post 29 of KKM. Here, the team which was going to be the committee in the seminar was formed.

d. Seminar and Training

After forming a committee and preparing the seminar, the seminar and training were held on May 12, 2018 in the hall of Panggung Jati, Taktakan at 9 A.M. It was attended by representatives of village officials and 27 housewives which represented local RT.

\section{Result and Discussion}

\subsection{Field Analysis}

In this activity, the team surveyed Panggung Jati. The survey showed that waste was still thrown away on roads and some resident's yards. We then interviewed the village officials, public figures and housewives. From the interview got information that waste management in Panggung Jati was handled independently in every household. Most people threw away their waste to the landfill. Some people even burn their waste in their yards. Some people had sorted their household waste. They sorted waste which could be sold to the junkman who went around the Panggung Jati. Meanwhile, waste which can't be sold (including organic waste) is disposed in temporary waste storage in front of people's houses. The waste is regularly collected by garbage picker and disposed in disposed in landfill. In landfill, the waste is burnt. The yards were also not used optimally. Based on the data, the team performed literature study on organic and inorganic waste management. Then, the team discussed the activities to be performed. From the discussion, the team decided to hold a seminar on organic and inorganic waste utilization on May 12, 2018.

\subsection{Program Socialization}

Before the seminar, the team performed socialization why distributing invitations to village officials, making brochures to be distributed to local food stalls and working with the caretaker of mosques to announce the activity. The team in this activity consisted of seminar committee which was conducted by Samsul Sahlan Hadi, a member of group 29 KKM from the Department of Industrial Engineering and other committee members. The other team was two advicers in the seminars, Sutarti, S.T., M.Eng. and Ratu Dea Mada Badriyah S.S., M.Pd. 


\subsection{Activity Implementation}

The seminar was held in the hall of Panggungjati, Taktakan. It was attended by several village officials, housewives and members of KKM 29. The seminar started at 9 A.M. with 27 participants. The seminar started with greetings from the head of the committee, representative of Panggung Jati officials and Field Supervisor. Afterward, the main event started.

\subsection{Team Formation}

The seminar gave a lot of knowledge to the people on the importance of appropriate waste management.

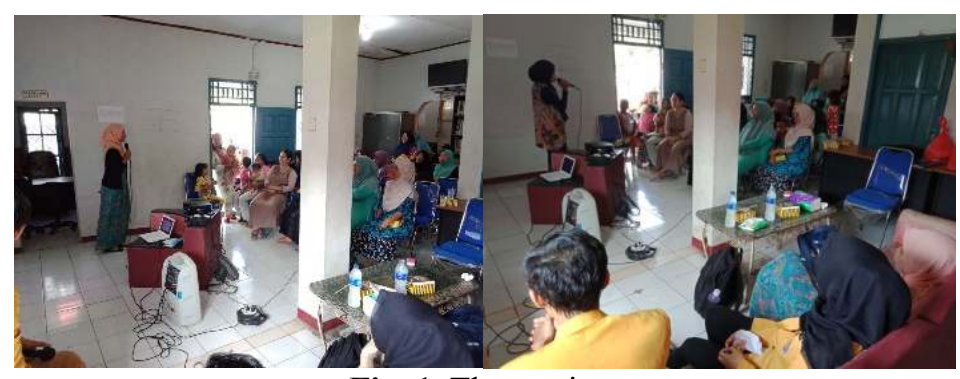

Fig. 1. The seminar

The material of the seminar was reminding the participants on Waste-Free Indonesia 2020.

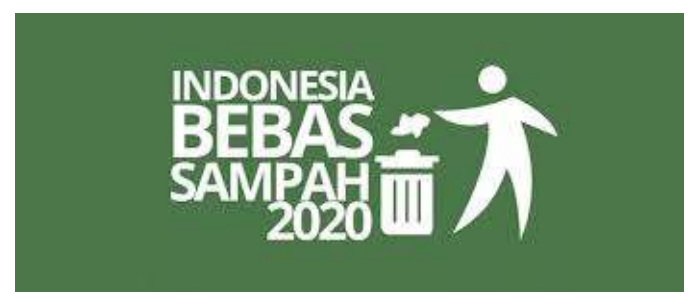

Fig. 2. Waste-Free Indonesia 2020

The definition of waste according to Indonesian Dictionary is goods which is disposed by the owner because it's no longer used or wanted, e.g. dirt, drink cans, leaves, papers, etc.. The instructor introduced the concepts of $3 R$ and 4R. 3R (reduce, reuse and recycle) waste management concept is expanded to face today's challenges and becomes $4 \mathrm{R}$ (reduce, reuse, recycle and replace). The concepts of $3 R$ and $4 R$ are to reduce waste from the sources as much as possible before being disposed to Landfill [5].

Concept of 4R:

1. Reduce

Reduce is an effort to decrease the usage of goods which may produce waste for people. Examples of reduce are:

a. Reduce buying bottles/cans because it will increase the existing waste. 
b. Buy less snacks, candies and other foods because the wrappers of the snacks and candies are made of plastic which is difficult to degrade, increasing the amount of waste. It would be better not to buy snacks, candies and other foods wrapped in plastic because it will help people avoid diseases since they're potentially harmful to people's health.

c. Avoid consumptive behaviors and only buy necessities.

\section{Reuse}

Reuse is a way to use waste again to reduce the amount of waste. Examples of reuse are:

a. Not throwing away plastic bags from markets or supermarkets. They can be used again when shopping or carrying something.

b. Reusing old and ripped dirty clothes as rags or doormats.

3. Recycle

Recycle is a way to recycle waste to be something useful. The collected waste is processed in such a way using creativity to earn money. Examples of recycle are:

a. Making crafts from old papers/newspapers.

b. Using old cloth from textile companies for clothes from recycles material.

c. Using used cans as pencil holder, piggy banks.

d. Using old newspapers for food wrappers.

\section{Replace}

Replace is an effort to replace old goods with more environmentally friendly goods. Examples of replace are:

a. Replacing plastic bags with biodegradable plastic bags.

b. Bringing lunch boxes instead of using sterofoam.

c. Replacing light bulbs with LED lamps which use less energy and are environmentally friendly.

\subsection{Utilization of Organic (Degradable) Waste}

Organic waste is described as waste which can decompose and degrade so they be used as compost. For example, food remnants, dry leaves, vegetables, etc.. Organic household wastes are usually food remnants, vegetable remnants and leaves of plants. Garlic skins, eggshells, corn husks, etc. can be used for crafts and decorations. Tumeric, papaya leaves, tobacco, soursop leaves, shallot skin etc. can be used as organic pesticides.

Other organic wastes can be used as compost [6][7]. The procedure of making compost are:

1. The simplest way is piling organic waste for a month.

2. Combining compost making and biopori using pipe.

3. Utilizing Buis to make compost and biopori with bigger size than pipe. Making compost using biopori has another advantage, i.e. storing ground water, thus increasing ground water level. Biopori can provide ground water reserve in the dry season. 


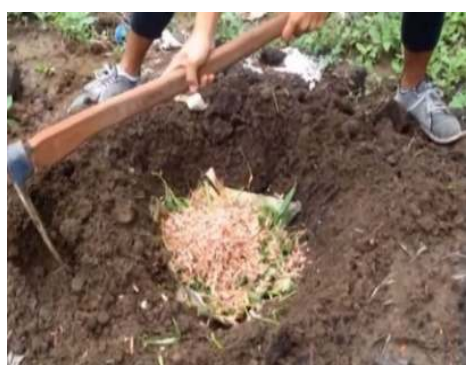

(a)

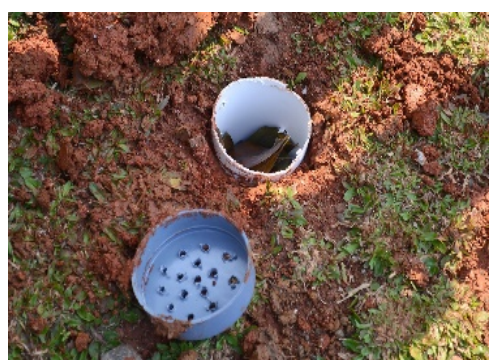

(b)

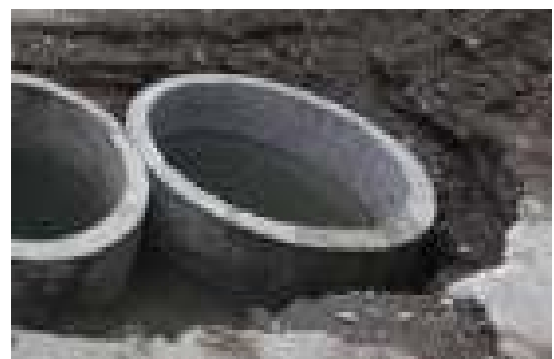

(c)

Fig. 3. (a) Making compost by piling soil (b) Making kompos by biopori using pipe (c) Making compost using buis

The remnants of some vegetables can be planted again easily, so they can be utilized and not wasted [8].

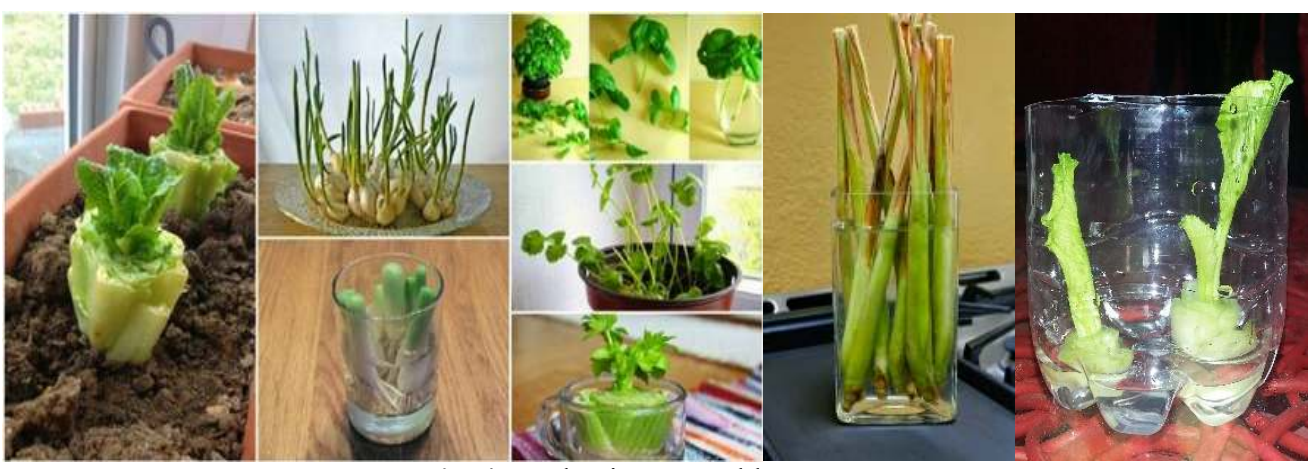

Fig. 4. Replanting vegetable remnant

Beside the vegetables above, there are other vegetables which can be replants, e.g. spinach, water spinach, chaya leaves, C. caudatus, basil, sweet potato, tomato, chili etc. Pineapple crown can also be easily replanted. 


\subsection{Utilization of Inorganic (Undegradable) Waste}

Inorganic waste is waste which difficult to decompose and can't degrade. However, nonorganic waste can be recycled into something new and useful, e.g. plastic bottles, old papers, cardboards, used cans, etc. Some of the most common inorganic wastes are glass and plastic bottle[8][9]. Glass and plastic bottle can be used as vegetable pot. This utilizes small land to produce vegetables at minimum cost. Planting vegetables can save expenses and produce quality vegetables and avoid chemical fertilizer and pesticide. It will also make the environment more beautiful. Figure 6 are examples of utilization of glass and plastic bottles as vegetable pots.

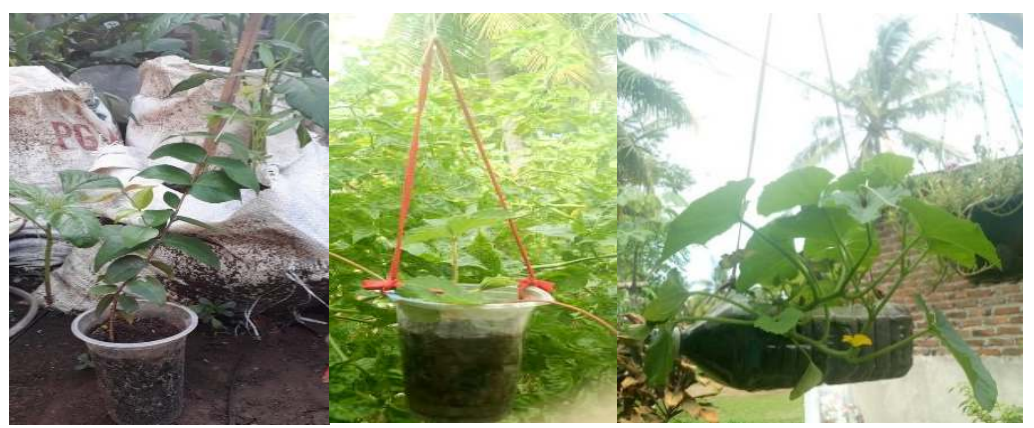

Fig. 6. Plastic cups and used bottle as seed and vegetable pots

Sacks and used tires can be used to grrow larger plants. The environmentally friendly pots can be used repeatedly because the materials are strong and durable.

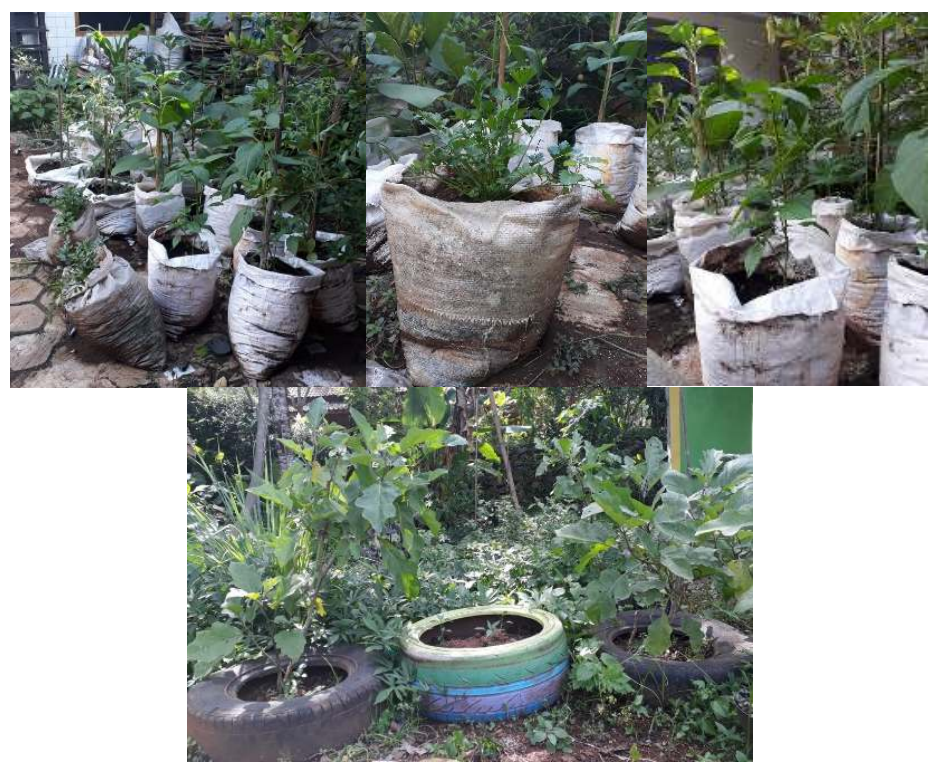

Fig. 7. Sacks and used tires as vegetable pots 
Beside as pots, plastic bottles and used plastics can also be used to make crafts with children [10]. It can enhance children's creativity. Below are examples of creations made of plastic cups and used plastics.

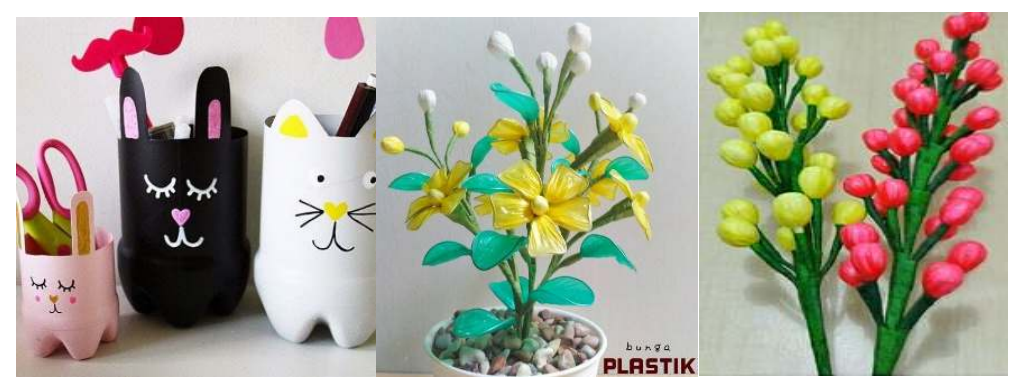

Fig. 8. Creations made of plastic bottles and used plastics

Old papers can be used to make attractive crafts which have sale values. Below are examples of crafts made of old papers.

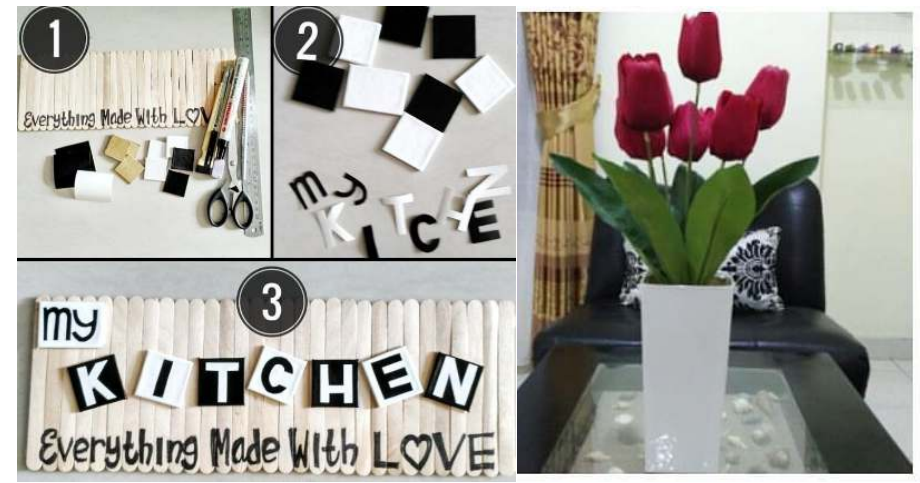

Fig. 9. Creations made of old papers

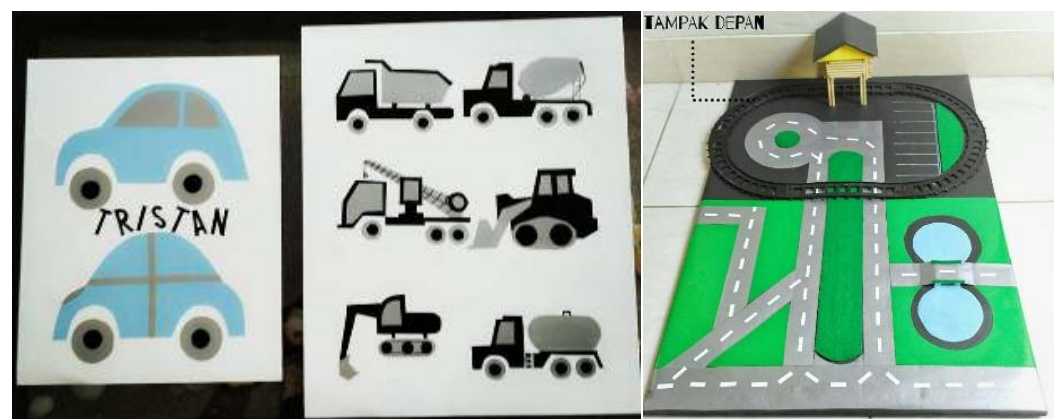

Fig. 10. Creations made of old papers for children's learning media 


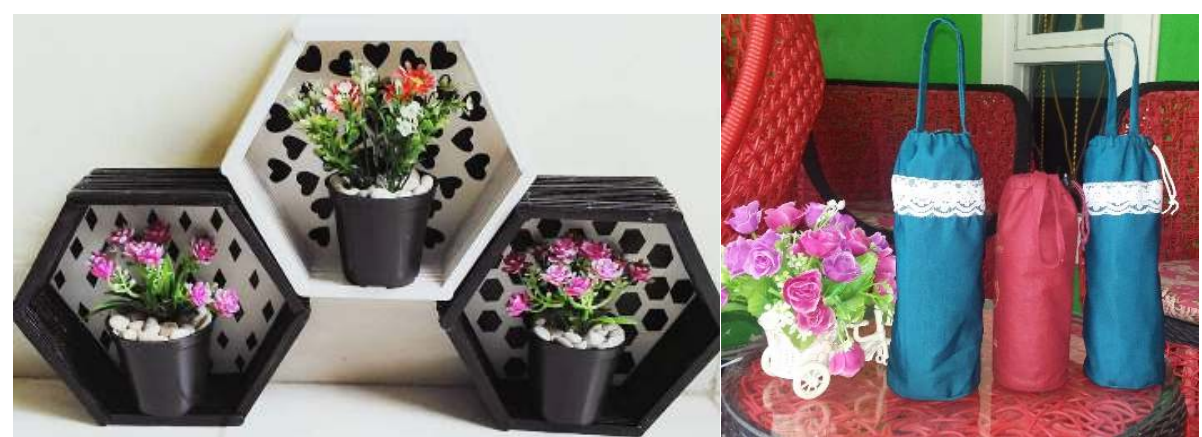

Fig. 11. Creations made of used wood and old fabric

Processing waste into crafts requires time and care. People who couldn't make crafts[10] could use the trash bank. Trash bank encouraged capacity building among people by developing independence and self-sufficiency by growing awareness, knowledge, and skills which encouraged participation to manage the environment in the community. Especially for women, knowledge and skill on waste processing stimulates creativity and innovation of waste recycling crafts [11]. Panggung Jati didn't have trash bank. Trash banks are implemented in many places and are proved to have positive impacts. Below is a simulation of trash bank system.

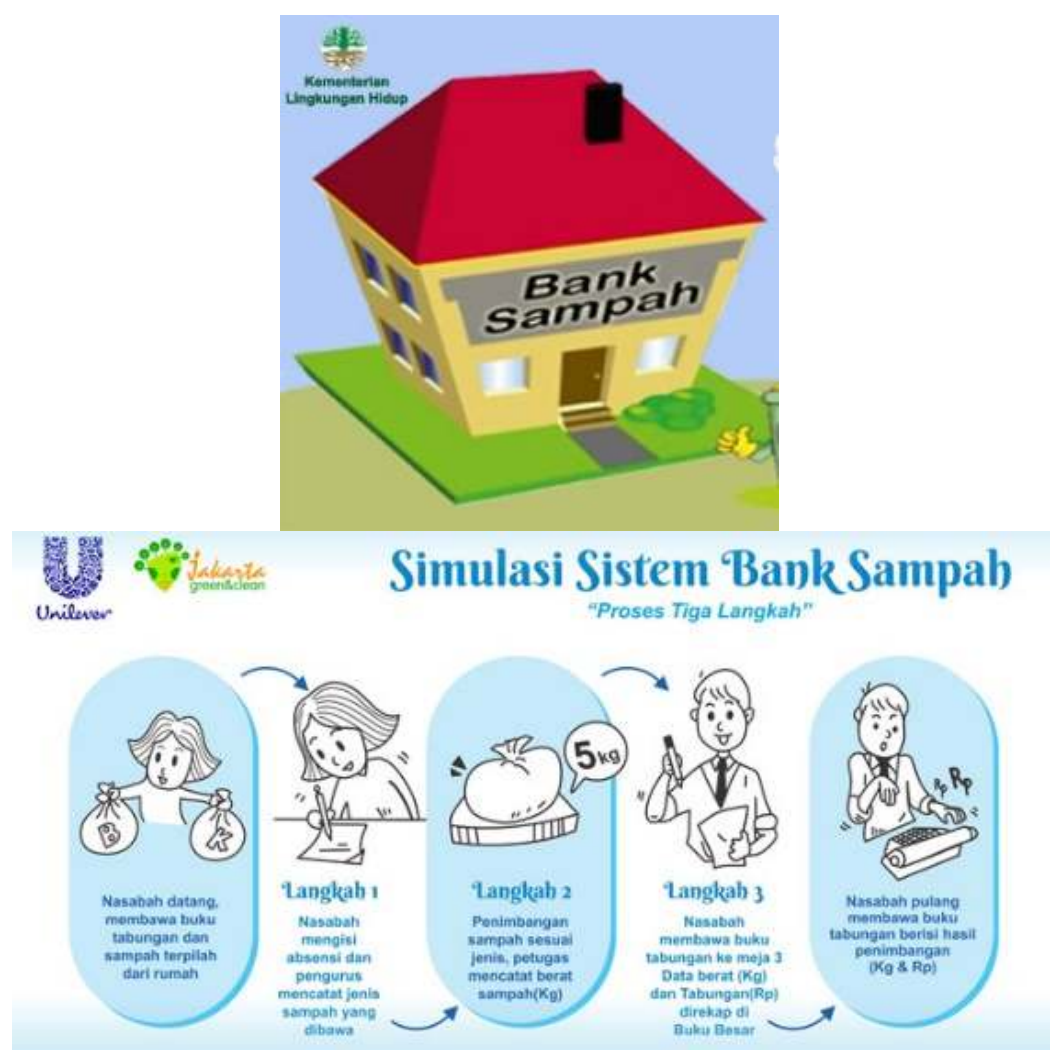

Fig. 12. Simulation of trash bank system 
At the end of the event, the participants watched examples of areas and villages which have successfully manage waste, as well as some videos on success by using waste. The videos were expected to motivate the participants to manage their wastes. During the seminar and training, people were very enthusiastic.

\section{Conclussion}

From the activities described above, it can be concluded that:

a. The seminar participants are excited to realize Waste-Free Indonesia 2020 Program.

b. People more understand about the 4R concept.

c. People more understand about the utilization of waste diversification of organic and inorganic waste.

d. People know and understand organic and inorganic waste management.

e. People understand the processing of organic and inorganic wastes into useful goods, are more motivated to manage household waste and use it to get extra income.

\section{Acknowledgments}

We'd like to thank Universitas Serang Raya which has financed this community service. Our gratitude for Mr. Supriyadi, the Headmen of Panggung Jati Urban Village, Mrs. Indah Sukartiningsih and the people of Panggung Jati for supporting this community service.

\section{References}

[1] Kinantan B Matondang A R and Hidayati J 2018 Waste management as an effort to improve urban area cleanliness and community income (journal review) IOP Conf. Series: Materials Science and Engineering 309 (2018) 012017 doi:10.1088/1757899X/309/1/012017

[2] Riswan Sunoko H and Hadiyarto A 2011 Pengelolaan sampah rumah tangga di kecamatan daha selatan Jurnal Ilmu Lingkungan. 9 (1) 31-38 https://doi.org/http:// dx.doi.org/ 10.14710/jil.9.1.31-38

[3] Napitupulu R Subhkan M and Nita L D 2011 Rancang Bangun Mesin Pencacah Sampah Plastik Jurnal Manutech 3 (1) 1-5

[4] Buku Potensi Desa Panggungjati 2018 Kelurahan Panggung Jati Kecamatan Taktakan Kota Serang

[5] Kusminah I L 2018 Penyuluhan 4R (Reduce, Reuse, Recycle, Replace) dan Kegunaan Bank Sampah sebagai Langkah Menciptakan Lingkungan yang Bersih dan Ekonomis di Desa Mojowuku Kabupaten Gresik Jurnal Pengabdian Masyarakat LPPM Untag Surabaya 03 (01): 22-28

[6] Badan Litbang Pertanian 2011 Pupuk Organik dari Limbah Organik Sampah Rumah Tangga Jakarta: Litbang Pertanian

[7] Jasminarni and Said Y M 2015 IbM Pengolahan Limbah Sampah Organik sebagai Pupuk Kebun Lingkungan Sekolah di Kabupaten Muaro Jambi Jurnal Pengabdian pada Masyarakat 30 (1) 30-34 
[8] Saif A 201512 Sayuran yang Bisa Anda tumbuhkan kembali Lagi dan Lagi. (http://www.omahijau.com/2015/05/12-sayuran-yang-bisa-anda-tumbuhkan.html) (April 10, 2018)

[9] Wahyuhastuti N Indiworo H E and Burhanuddin A 2017 IbM Pengolahan Sampah Plastik dalam Rangka Pemberdayaan Masyarakat Kelurahan Muktiharjo Kidul Semarang Jurnal Aplikasi Teknik dan Pengabdian Masyarakat 1 (2), 82-85

[10] Rahaldi I 201712 Ide Kreatif Daur Ulang Botol Plastik, Bisa Dicontoh Nih! (https://www.dream.co.id/unik/dari-pada-jadi-limbah-gunakan-sampah-botolplastikmu-untuk-170822o.html) (April 10, 2018)

[11] Asteria D and Heruman H 2016 Bank Sampah sebagai Alternatif Strategi Pengelolaan Sampah Berbasis Masyarakat di Tasikmalaya Jurnal Manusia dan Lingkungan 23 (1): 136-141 